\title{
The Effects of Total Mixed Ration and Separate Feeding on Lactational Performance of Dairy Cows
}

\author{
Muhanned E. M. Awlad Mohammad ${ }^{1}$, Murat Gorgulu' ${ }^{1 *}$ and Serap Goncu ${ }^{1}$ \\ ${ }^{1}$ Faculty of Agriculture, University of Cukurova, 01330 Adana, Turkey.
}

\begin{abstract}
Authors' contributions
This work was carried out in collaboration between all authors. Author MG designed the study, performed the statistical analysis, wrote the protocol and the first draft of the manuscript. Author MEMAM carried out the experiment with cows. Author SG managed the literature searches and wrote the manuscript. All authors read and approved the final manuscript.

Article Information

DOI: $10.9734 / A R J A / 2017 / 33663$

Editor(s):

(1) Fábio da Costa Henry, Laboratory of Food Technology, State University of Northern of Rio de Janeiro, Brazil.

Reviewers:

(1) Sabri Gül, Mustafa Kemal University, Hatay, Turkey. (2) Marcio Da Silva Vilela, Federal Institute of Maranhão, Brazil. Complete Peer Review History: http://www.sciencedomain.org/review-history/19843
\end{abstract}

Original Research Article

Received $25^{\text {th }}$ April 2017

Accepted $28^{\text {th }}$ June 2017

Published $4^{\text {th }}$ July 2017

\begin{abstract}
The aim of this study was to investigate the effects of different feeding systems on milk production and milk composition of dairy cows. Thirty-two dairy cows having similar lactation number, Days in Milk (DIM), live body weight and milk production was divided into four groups. First group received Total Mixed Ration (TMR) ad libitum, second group received roughage and concentrate limited and separately in two meals, third group fed with partial TMR which included half of the concentrate in roughage part of the diet and remained concentrate was offered in two meals, and the last group was fed with roughage and concentrate separately and roughage was offered limited in two meals and concentrate was offered limited in four meals. The feeding systems affected dry matter intake $(\mathrm{P}<0.05)$. Limited feeding groups were fed on roughage and concentrate separately, the roughage intake in these groups was decreased, concentrate ratio was increased in the diet as well especially in the group receiving concentrate in two meals $(P<0.05)$. In TMR group, milk yield was significantly increased due to increase in their feed intake $(P<0.05,2 \mathrm{~kg} /$ day higher than others). Milk total solid, fat and urea nitrogen contents were affected by feeding systems. Restricted and separate feeding system groups had lower total solid, fat and urea nitrogen in milk $(P<0.05)$. In conclusion, the results showed that restricted and separate feeding of concentrate and roughage may not be applicable in practice as it decreased feed intake, milk yield and milk fat test.
\end{abstract}


Keywords: Feeding systems; milk yield; milk composition; dairy cows.

\section{INTRODUCTION}

Different feeding systems are available for dairy cow in practice such as standard feeding, strategic feeding, feeding complete diet (Total mixed ration: TMR) [1,2], strategic or partial TMR [2], and choice (cafeteria) feeding [3]. Standard feeding refers feeding dairy cows according to current milk yield and live weight. In which all feeds are supplied restricted, individually and separately to the animal. In strategic feeding, concentrate is used restrictively and independent from milk yield and roughage is used ad libitum. This system may be applied by using concentrate in constant amount in early lactation and later may be decreased according to milk yield as well. Concentrate may be also supplied by milking system or automatic station feeder in strategic feeding. Complete feeding (TMR) is applied by mixing concentrate and roughage with mixer and delivered to animal ad libitum. Strategic TMR is a mixture of strategic and TMR feeding systems. TMR may not cover nutrient requirements of high yielding cows and extra concentrate can be supplied in automatic station feeder. This could be applied as partial TMR to overcome the ruminal problem due to high and separate concentrate usage. Recently choice feeding (supplying feed ingredient separately, simultaneously and ad libitum) is considered as a feeding system for small ruminants $[4,5,6,7]$, and some studies are also available in dairy cattle $[8,3]$.

Main differences of these feeding systems are ways of supply of concentrate and level of feeding (restricted or ad libitum). Increasing concentrate in the diet or using separately may reduce rumen $\mathrm{pH}$ and digestibility of dietary fiber $[9,10]$. TMR is a proper feeding system to solve problem with low ruminal $\mathrm{pH}$ which is having a negative effect on the microbial growth and milk fat content [11,12,13]. Similarly, free choice feeding, offers a chance to the animals to select their diet $[4,8,14,15]$ and balance rumen condition [14,3], and thus it may have a potential advantage in ruminant feeding. Other ways of alleviating separate concentrate usage are to increase concentrate feeding frequency or use some of concentrate with roughage such as in partial TMR and/or strategic TMR application.

Shabi et al. [16], revealed that high concentrate and highly degradable starch using in diet may increase fluctuation of rumen $\mathrm{pH}$, ruminal ammonia, volatile fatty acids and these fluctuations may be controlled and milk yield and the components may be improved by increasing feeding frequency from 2 to 4 . Similarly, Devries et al. [17] reported that increasing feeding frequency from 1 to 4 times may decrease sorting and variation of consumed diet. However, some researchers $[18,19]$, reported better results with single feeding compared to frequent feeding. They explained the results with increase aggressive behavior and less time for resting during feed delivery with frequent feeding.

Generally, small dairy farms supply concentrate during milking separately from the roughage and all feeds supplied restricted. Much of the milk production is supplied by these types of farms especially underdeveloped and developing countries. Thus, it is very important to show the effects of limited and separate feeding of concentrate. The present study was therefore aimed to test ad libitum TMR, standard feeding, restricted feeding with partial TMR and concentrate and restricted feeding with roughage and restricted but frequent feeding of concentrate on milk yield and milk composition of dairy cows.

\section{MATERIALS AND METHODS}

Study was carried out in Dairy Farm at Cukurova Universitiy, Faculty of Agriculture, Department of Animal Science located 3702 '37"N, long. 3522 '21"E, approximately $127 \mathrm{~m}$ above sea level, from January to February, 2014 and lasted 8 weeks. The climate in this region is relatively warm, with a mean temperature of about $12^{\circ} \mathrm{C}$ and relative humidity $66 \%$. Thirty-two lactating Holstein cows were divided into four feeding regimes in a Completely Randomized Design according to their milk yield, parities, and body weights. The cows had about 75 days in milk and $34 \mathrm{~kg}$ milk yield, $555 \mathrm{~kg}$ average body weight. Animals were housed and maintained according to the approval of animal care and use Ethical Committee of Cukurova University during the trial.

A standard TMR (Table 1) were formulated according to NRC [20] with about $22 \mathrm{~kg} \mathrm{DM} /$ day and the four feeding regimes were designed according to this TMR and dry matter intake. Feeding regimes were 1) ad libitum TMR in two meals, 2) roughage and concentrate in standard TMR were supplied separately and restrictedly in two meals (standard feeding), 3) half of concentrate in standard TMR were included to 
Table 1. Standard diet used in ad libitum TMR and the diet consumed in different feeding regimes (\%)

\begin{tabular}{|c|c|c|c|c|}
\hline Roughage & Ad libitum TMR & $\mathbf{R 2 X}$ & RpTMR2X & $\mathbf{R 2 X}$ \\
\hline Concentrate & & C2X & $\mathrm{C} 2 \mathrm{X}$ & C4X 4 Meal \\
\hline Corn & 18.44 & 19.10 & 18.35 & 18.67 \\
\hline Barley & 5.00 & 5.19 & 5.00 & 5.09 \\
\hline Beet molasses & 1.20 & 1.23 & 1.20 & 1.21 \\
\hline Sunflower meal & 11.09 & 11.48 & 11.05 & 11.22 \\
\hline Fulfat soybean & 7.50 & 7.78 & 7.50 & 7.65 \\
\hline Corn gluten meal & 2.50 & 2.55 & 2.45 & 2.50 \\
\hline Wheat bran & 9.20 & 9.57 & 9.20 & 9.35 \\
\hline Soy oil & 0.60 & 0.64 & 0.63 & 0.64 \\
\hline Alfalfa hay & 16.40 & 15.58 & 16.50 & 16.10 \\
\hline Corn silage & 26.20 & 24.87 & 26.30 & 25.69 \\
\hline Limestone & 0.90 & 0.94 & 0.90 & 0.93 \\
\hline Dicalcium phosphate (DCP) & 0.60 & 0.60 & 0.57 & 0.58 \\
\hline Salt & 0.20 & 0.21 & 0.20 & 0.21 \\
\hline Sodium bicarbonate & 0.16 & 0.17 & 0.16 & 0.17 \\
\hline Vitamin-Mineral Premix & 0.09 & 0.09 & 0.08 & 0.08 \\
\hline \multicolumn{5}{|l|}{ Nutrient content; } \\
\hline Dry Matter, \% & 61.83 & 62.88 & 61.80 & 62.25 \\
\hline Net Energy (NEI), Mcal/kg DM & 1.58 & 1.60 & 1.60 & 1.60 \\
\hline Crude protein $(\mathrm{CP}), \% \mathrm{DM}$ & 16.89 & 17.09 & 16.90 & 16.98 \\
\hline MP, \%DM * & 10.75 & 10.77 & 10.67 & 10.73 \\
\hline Rumen Undegradable Protein (RUP),\%DM * & 5.93 & 5.87 & 5.76 & 5.85 \\
\hline Rumen Degradable Protein (RDP), \%HP * & 65.25 & 65.64 & 65.90 & 65.56 \\
\hline Fat, \%DM & 4.60 & 4.66 & 4.58 & 4.63 \\
\hline Ash, \%DM & 6.98 & 6.99 & 6.97 & 7.00 \\
\hline Neutral Detergent Fiber (NDF), \%DM & 35.40 & 34.97 & 35.44 & 35.22 \\
\hline Acid detergent Fiber (ADF),\%DM & 21.95 & 21.51 & 21.98 & 21.77 \\
\hline Non Fiber Carbohydrate, \%DM & 38.57 & 38.70 & 38.51 & 38.57 \\
\hline Lysine, \%MP * & 5.96 & 6.00 & 6.03 & 6.01 \\
\hline Methionine, \%MP * & 1.93 & 1.94 & 1.94 & 1.94 \\
\hline Lysine/methionine * & 3.10 & 3.10 & 3.11 & 3.10 \\
\hline
\end{tabular}

R2X: Restricted and 2 meals, R4X: Restricted and 4 meals, RpTMR2X: Restricted partial TMR and 2 meals, ${ }^{*} N R C$ [20] supply

roughage to construct a partial TMR (pTMR) and partial TMR and remaining concentrate were supplied to cows restricted and separately in two meals 4) roughage in standard TMR were supplied in two meals and concentrate were supplied in 4 meals, separately and restrictedly. The cows were kept in individual paddock having $3 \times 6 \mathrm{~m}$ size. The cows fed in two meals received their diet at 06:00 and 18:00 and the cow fed in four meals received their diet at 06:00, 12:00, 18:00 and 24:00. Fresh water was available freely.

Chemical compositions of feed ingredients were determined according to the standard Official Methods of Analysis (AOAC) [21]. Neutral Detergent Fiber (NDF) and Acid Detergent Fiber
(ADF) were analyzed by using ANKOM fiber analyzer [22]. Ingredient composition of single fed diet and its chemical contents are given in Table 1. Live weight change was determined weekly and milk yield and feed intake were determined daily. Animals were milked at 05:00 in the morning and at 17:00 in the afternoon and milk samples were taken from morning and afternoon milk and analyzed by MilkoscanFT-120 (Foss, DK) weekly and their compositions were recalculated according to portion of morning and afternoon milk in the total milk.

The study was carried out in a completely randomized design and data were analyzed GLM procedure of SAS [23] and means were separated with Duncan Multiple Range Test. 


\section{RESULTS AND DISCUSSION}

The standard TMR was formulated according to the age, the initial live weight, the condition score and the milk yield of the cows and environmental conditions. All concentrates supplied were consumed in the groups fed separately but roughages were not consumed totally in those groups although roughages were supplied limited amount. High concentrate intake resulted in decrease roughage intake in other studies $[26,27,28,30]$, when concentrate and roughage were supplied separately. Thus roughage/concentrate ratio of the diets for separate feeding groups was changed. Ad libitum TMR had $43.5 \%$ roughage, but the cows receiving concentrate separately except partial TMR groups increased concentrate ratio in the diet significantly $(P<0.01)$. The cows fed with adlibitum TMR consumed more dry matter and nutrients as expected and this resulted in increase in milk yield $(P<0.05)$ compared to separate feeding groups. High feed intake in TMR feeding groups increased body weight gain due to better energetic status compared to the other feeding groups.

It is well known that ad libitum TMR feeding increase feed intake and may improve lactation performance [13,24] as the system provides more stable rumen environment and supply synchrony in nutrients for rumen microorganisms and the host animal $[24,25]$.

As noted before, separate feeding decreased roughage intake and increased concentrate in their diets $[26,27,28]$. It is well known that high concentrate may improve nitrogen utilization efficiency in the rumen [20,29], and may decrease milk urea nitrogen as found in this study. Agnew et al. [30] reported that high concentrate increased nitrogen utilization efficiency and protein content of milk. Similarly Godden et al. [31], revealed that milk urea nitrogen concentrations had a positive relationship with dietary levels of Crude protein $(\mathrm{CP})$, Rumen Degradable Protein (RDP), and Rumen Un degradable Protein (RUP), and a negative relationship with levels of Non Fiber Carbohydrate (NFC), and with the ratios of NFC:CP, NFC:RDP, NFC:RUP. Accordingly, the cows fed with separate and restrictedly increased concentrate ratio in the diet and decreased milk urea nitrogen in the present study.

Separate feeding decreased roughage content of the diets consumed this is the basic reason of low milk fat test in many dairy farms.

Table 2. Lactational performance of the cows fed different feeding regimes

\begin{tabular}{lllllll}
\hline Roughage & Ad libitum & R2X & RpTMR2 & R2X & SEM & (P<) \\
\cline { 3 - 6 } Concentrate & TMR & R2X & R2X & R4X & & \\
\hline Roughage, \% DM & $43.5 \mathrm{a}$ & $40.7 \mathrm{~b}$ & $42.2 \mathrm{ab}$ & $41.7 \mathrm{~b}$ & 0.01 & 0.01 \\
Body weight change, kg & $22.2 \mathrm{a}$ & $5.0 \mathrm{~b}$ & $-4.3 \mathrm{~b}$ & $6.3 \mathrm{~b}$ & 6.16 & 0.04 \\
Milkyield, kg/day & $34.4 \mathrm{a}$ & $32.6 \mathrm{~b}$ & $31.8 \mathrm{~b}$ & $32.8 \mathrm{~b}$ & 0.52 & 0.02 \\
Milk yield change, kg & $1.5 \mathrm{a}$ & $-1.4 \mathrm{~b}$ & $-2.2 \mathrm{~b}$ & $-1.8 \mathrm{~b}$ & 0.73 & 0.01 \\
Dry matter intake, DMI,kg/day & $23.4 \mathrm{a}$ & $21.2 \mathrm{~b}$ & $20.8 \mathrm{~b}$ & $21.2 \mathrm{~b}$ & 0.51 & 0.01 \\
MPE (MilkYield/DMI) & 1.5 & 1.5 & 1.5 & 1.6 & 0.04 & 0.59 \\
Milk compositions; & & & & & & \\
Dry Matter, \% & $12.18 \mathrm{a}$ & $11.19 \mathrm{~b}$ & $11.25 \mathrm{~b}$ & $11.22 \mathrm{~b}$ & 0.48 & 0.02 \\
Fat, \% & $3.31 \mathrm{a}$ & $2.14 \mathrm{~b}$ & $2.21 \mathrm{~b}$ & $2.31 \mathrm{~b}$ & 0.55 & 0.01 \\
Protein, \% & 3.14 & 3.31 & 3.22 & 3.14 & 0.08 & 0.50 \\
Lactose, \% & 4.75 & 4.67 & 4.77 & 4.72 & 0.04 & 0.70 \\
Casein, \% & 2.55 & 2.61 & 2.58 & 2.52 & 0.04 & 0.80 \\
Urea-N, mg/dL & $19.2 \mathrm{a}$ & $16.2 \mathrm{~b}$ & $19.1 \mathrm{ab}$ & $20.1 \mathrm{a}$ & 1.70 & 0.02 \\
Nutrient intakes; & & & & & & \\
NEL, Mcal/day & 36.6 & 34.2 & 33.1 & 34.3 & & \\
Rumen Undegradable Protein, g/day & 1375 & 1256 & 1191 & 1254 & & \\
Crude protein (CP), g/day & 3914 & 3655 & 3492 & 3643 & & \\
Neutral Detergent Fiber (NDF kg/day) & 8.2 & 7.3 & 7.3 & 7.6 & & \\
Acid Detergent Fiber (ADF) kg/day & 5.1 & 4.6 & 4.5 & 4.7 & & \\
\hline \multicolumn{1}{r}{ MPE: Milk production efficiency, R2X: Restricted and 2 meals, R4X: Restricted and 4 meals, } &
\end{tabular}

RpTMR2X: Restricted partial TMR and 2 meals 
Many studies [32,33,34,35] reported that high concentrate diet may decrease rumen $\mathrm{pH}$, cellulose digestibility and acetate/propionate ratio in the rumen causing lower milk fat test. On the other hand, the amount of concentrate supplied in separate feeding is another issues for ruminal fermentation, high starch load in a short time may interfere the ruminal condition and aggravate low milk test $[36,37,38]$. High concentrate and high starch load to rumen may decrease acetate (ruminal effects), [24] production which is main precursors of de novo milk fatty acid synthesis in mammary tissues and increase trans $\mathrm{C} 18: 1$ fatty acid in the rumen $[39,40,41,35]$, during biohydrogenation of polyunsaturated fatty acids in the rumen known as inhibiting enzymes (post ruminal effect) $[42,43]$, for milk fatty acid synthesis in mammary tissues.

Frequent feeding with concentrate or partial TMR use to limit the load of concentrate to rumen are alternatives approaches to minimize negative effects of separate feeding. Some researchers $[44,45,46]$, reported better feed intake and improvements in milk protein and fat contents with frequent feeding, but some others $[47,48,49,50]$, did not observe any differences, and Fan et al. [51], revealed that ad libitum roughage and 4 times concentrate supply was better feeding regimes for dairy cows during warm season. However, frequent feeding with concentrate or partial TMR usage did not improve any performance parameters of the dairy cows in the present study. There are marked variations of the results obtained with different feeding systems. These could be attributed to genotypes, milk yield, stage of lactation, season, feed sources and quality, and amount of concentrate used daily. TMR feeding is a good practice for many dairy farms and has higher milk yield and more stable milk components $[13,24]$ compared separate feeding regimes such as in the present study.

\section{CONCLUSIONS}

The results showed that separate feeding regimes under restricted feeding conditions were not advisable for practice as it decreased feed intake, and roughage/concentrate ratio, milk yield and milk fat test significantly.

\section{COMPETING INTERESTS}

Authors have declared that no competing interests exist.

\section{REFERENCES}

1. Ostergaard V, Krohn CC, Thysen I. Feeding principles and optimum feeding of high yielding dairy cows. In: Research and Cattle Production. Danish Status and Perspectives. Contribution in Honour of A. Neimann-Sørensen.

Landhusholdningsselskabet, Denmark. 1987;126-139.

2. Gorgulu M. Büyük ve Kücükbas Hayvan Besleme Kitabi. C.U. Ziraat Fakültesi Genel Yayin No: 244. Ders Kitaplari Yayin No: A78. Adana; 2002.

3. Boga M, Gorgulu M, Sahin A. Effects of feeding methods, season and production level on lactation performance and feeding behaviour of dairy cows. Bulgarian Journal of Agricultural Science. 2014;20(4):915923.

4. Gorgulu M, Kutlu HR, Demir E, Oztürkcan $\mathrm{O}$, Forbes JM. Nutritional consequances of free-choice among feed ingredients by Awassi lambs. Small Ruminant Research. 1996;20:23-29.

5. Rodriguez $A B$, Bodas $R$, Fernandez $B$, Lopez-Campos O, Mantecon AR, Giraldez FJ. Feed intake and performance of growing lambs raised on concentratebased diets under cafeteria feeding systems. Animal. 2007;1(3):459-466.

6. Gorgulu M, Boga M, Sahin A, Serbester U, Kutlu HR, Sahinler S. Diet selection and eating behaviour of lactating goats subjected to time restricted feeding in choice and single feeding system. Small Ruminant Research. 2008;78(1-3):41-47.

7. Şahin A, Keskin M, Biçer O, Gül S. Diet selection by Awassi lambs fed individually in cafeteria feeding system. Livestock Production Science. 2003;82:163-170.

8. Gorgulu M, Akyol MA, Boga M, Goncu S. The effects of choice feeding and season on feeding behavior and growth performance of calves. Journal of Animal and Feed Sciences. 2012;21:263-275.

9. Archimede $H$, Sauvant $D$, Herview J, Poncet C, Dorleans M. Digestive interactions in the ruminant: Relationships between whole tract and stomach evaluation. Animal Feed Science and Technology. 1995;54:327-340.

10. Nikkah A. Feeding frequency interfacing tradition and modernity in dairy production: Feeding behavior insights. Journal of Animal and Poultry Science. 2013;2(4):9197. 
11. Fox DG, Sniffen CJ, O'Conor JD, Russell JB, VanSoest PJ. The Cornell net carbohydrate protein system for evaluating cattle diets. Search agriculture. Cornell University, Agriculture Experimental Station, No. 34. Ithaca, NY; 1990.

12. Linn JG, Hutjens MF, Shaver R, Otterby DE, Howard WT, Kilmer LH. Feeding the dairy herd. North Central Regional Extension Publ. No. 346. Minnesota Extension Service. University of Minnesota, College of Agriculture; 1994.

13. Gordon FJ, Patterson DC, Yan T, Porter MG, Mayne CS, Unsworth EF. The influence of genetic index for milk production on the response to complete diet feeding and the utilization of energy and nitrogen. Animal Science. 1995;61: 199-210.

14. Fedele V, Claps S, Rubino R, Calandrelli M, Pilla AM. Effect of free-choice and traditional feeding systems on goat feeding behaviour and intake. Livest. Prod. Sci. 2002;74:19-31.

15. Keskin $M$, Şahin A, Biçer O, Gül S. Comparison of the behaviour of Awassi lambs in cafeteria feeding system with single diet feeding system. Applied Animal Behaviour Science. 2004;85:57-64.

16. Shabi Z, Arieli A, Bruckental I, Aharoni Y, Zamwel S, Bor A, Tagari H. Effect of the synchronization of degradation of dietary crude protein and organic matter and feeding frequency on ruminal fermentation and flow of digesta in the abomasum of dairy cows. J. Dairy Sci. 1998;81:19912000.

17. Devries TJ, VonKeyserlingk MA, Beauchemin KA. Frequency of feed delivery affects the behavior of lactating dairy cows. J. Dairy Sci. 2005;88(10): 3553-3562.

18. Phillips CJC, Rind MI. The effects of frequency of feeding and total mixed ration (TMR) on the production and behavior of dairy cows. J. Dairy Sci. 2001;84:19791987.

19. Mantysaari P, Khalili H, Sariola J. Effect of feeding frequency of total mixed ration on the performance of high-yielding dairy cows. J. Dairy Sci. 2006;39:4312-4320.

20. NRC. Nutrient requirements of dairy cattle. Seventh revised edition. National Academy Press. Washington, D.C.; 2001.

21. AOAC. Officifal methods of analysis. $16^{\text {th }}$ Ed., 4th Revision, Association of Official Analytical Chemists, Arlington, VA; 1998.
22. Van Soest PJ, Robertson JB, Lewis BA. Methods for dietary fiber, neutral detergent fiber, and nonstarch polysaccharides in relation to animal nutrition. J. Dairy Sci. 1991;74:3583-359.

23. SAS. SAS user's guide: Statistics, version 8.0. SAS Inst. Inc., Cary, NC, USA; 2000.

24. Bargo F, Muller LD, Delahoy JE, Cassidy TW. Milk response to concentrate supplementation of high producing dairy cows grazing at two pasture allowances. J. Dairy Sci. 2002;85:1777-1792.

25. Li DY, Lee SS, Choi NJ, Lee SY, Sung HG, Ko JY, Yun SG, Ha JK. Effects of feeding system on rumen fermentation parameters and nutrient digestibility in Holstein steers. Asian-Australasian J. Anim. Sci. 2003;16:1482-1486.

26. Ingvartsen $\mathrm{KL}$, Aaes $\mathrm{O}$, Andersen JB. Effects of pattern of concentrate allocation in the dry period and early lactation on feed intake and lactational performance in dairy cows. Livest. Prod. Sci. 2001;71:207221.

27. Bach A, Iglesias C, Calsamiglia S, Devant M. Effect of amount of concentrate offered in automatic milking systems on milking frequency, feeding behavior, and milk production of dairy cattle consuming high amounts of corn silage. J. Dairy Sci. 2007;90:5049-5055.

28. Moujahed N, Dabboussi I, Bel Haj Ammar S, Darej S. Effects of concentrate feeding strategy on milk production and composition in dairy cows. Research $\mathrm{J}$. Dairy Sci. 2009;1:3-7.

29. Pathak AK. Review: Various factors affecting microbial protein synthesis in the rumen. Veterinary World. 2008;1(6):186189.

30. Agnew KW, Mayne CS, Doherty JG. An examination of the effect of method and level of concentrate feeding on milk production in dairy cows offered a grass silage-based diet. Animal Science, 1996;63:21-31.

31. Godden SM, Lissemore KD, Keton DF, Leslie KE, Walton JS, Lumsden JH. Factors associated with milk urea concentrations in Ontario dairy cows. J. Dairy Sci. 2001;84:107-114.

32. Bauman DE, Davis CL, Bucholtz HF. Propionate production in rumen of cows fed either a control or high grain, low fibre diet. J. Dairy Sci. 1971;54:1282-1287.

33. Hoover WH, Kincaid CR, Varga GA, Thayne WV, Junkins LL. Effects of solids 
and liquid flows on fermentation in continuous cultures: IV. $\mathrm{pH}$ and dilution rate. J. Anim. Sci. 1984;58:692-699.

34. Arieli A, Shabi Z, Bruckental I, Tagari H, Aharoni Y, Zamwell S, Voet H. Effect of the degradation of organic matter and crude protein on ruminal fermentation in dairy cows. J. Dairy Sci. 1996;79:1774-1780.

35. Overton TR, AL, Lock WP, James, Bauman DE. Troubleshooting milk fat challenges on commercial dairy farms. Proc. Anim. Nutr. Assoc. of CanadaEastern Nutr. Conf. 2006;127-137.

36. Satter LD, Baumgardt BR. Changes in digestive physiology of the bovine associated with various feeding frequency. J. Anim. Sci. 1962;21:897-900.

37. Robinson PH. Dynamic aspects of feeding management for dairy cows. J. Dairy Sci. 1989;72:1197-1209.

38. Plaizier JC, Krause DO, Gozho GN, Mcbride BW. Subacute ruminal acidosis in dairy cattle: The physiological causes, incidence and consequences. The Veterinary Journal. 2007;176(1):21-31.

39. Griinari JM, Dwyer DA, McGuire MA, Bauman DE, Palmquist DL, Nurmela KVV. Trans-octadecanoic acids and milk fat depression in lactating dairy cows. J. Dairy Sci. 1998;81:1251-1261.

40. Bauman DE, Baumgard LH, Corl BA, Griinari JM. Biosynthesis of conjugated linoleic acid in ruminants; 1999.

Available:http://www.agrireseau.qc.ca/bovi nsboucherie/documents/CLA.pdf

(Accessed 25 April 2015)

41. Dhiman TR, Zaman MS, Macqueen IS, Boman RL. Influence of corn processing and frequency of feeding on cow performance. J. Dairy Sci. 2002;85:217-226.

42. Bauman DE, Griinari JM. Regulation and nutritional manipulation of milk fat: Low-fat milk syndrome. Livest. Prod. Sci. 2001;70: 15-29.
43. Harvatine KJ, Boisclair YR, Bauman DE. Recent advances in the regulation of milk fat synthesis. Animal. 2009;3(1):40-54.

44. Yun SK, Han JD. Effect of feeding frequency of concentrate to milking cow in early lactation on $\mathrm{pH}$ and VFAconcentration in rumen fluid and on milk composition and milk yield. AsianAustralasian J. Anim. Sci. 1989;2(3):418420.

45. Yang CM, Varga GA. Effect of three concentration feeding frequencies on rumen protozoa, rumen digesta, and milk yield in dairy cows. J. Dairy Sci. 1989;72: 950-957.

46. Rottman LW, Ying Y, Zhou K, Bartell PA, Harvatine KJ. The daily rhythm of milk synthesis is dependent on the timing of feed intake in dairy cows. Physiological Reports 2. 2014;2(6):e12049,1-6.

47. Gill MS, Castle ME. The effects of the frequency of feeding concentrates on milk production and eating behavior in Ayrshire cows. Animal Production. 1983;36:79-85.

48. Nocek JE, Steele RL, Braund DG. Performance of dairy cows fed forage and grain separately versus a total mixed ration. J. Dairy Sci. 1986;69:2140-2147.

49. Yan T, Patterson DC, Gordon FJ. The effect of two methods of feeding the concentrate supplement to dairy cows of high genetic merit. Animal Science. 1998;67:395-403.

50. Yrjanen S, Kaustell K, Kangasniemi R, Sariola J, Khalili H. Effects of concentrate feeding strategy on the performance of dairy cows housed in a free stall barn. Livest. Prod. Sci. 2003;81(2-3):173-181.

51. Fan YK, Lin YL, Chiou PWS. Effect of concentrate feeding frequency versus total mixed ration on lactational performance and ruminal characteristics of Holstein cows. Asian-Australasian J. Anim. Sci. 2002;15:658-664.

(c) 2017 Mohammad et al.; This is an Open Access article distributed under the terms of the Creative Commons Attribution License (http://creativecommons.org/licenses/by/4.0), which permits unrestricted use, distribution, and reproduction in any medium, provided the original work is properly cited.

Peer-review history:

The peer review history for this paper can be accessed here: http://sciencedomain.org/review-history/19843 